\title{
Socio-economic Features of the Formation of Migration Processes in the North Caucasus
}

\author{
Shamil Gimbatov ${ }^{1 *}$ \\ ${ }^{I}$ Institute of Socio-Economic Research of the Dagestan Federal Research Centre of the Russian Academy of Sciences, \\ Makhachkala, Russia \\ *Email: gimba@list.ru
}

\begin{abstract}
The paper analyses the effectiveness of interregional migration in the North Caucasus Federal District regions. The main trends and conditions in which migration processes are formed in the region and the main structural and socio-economic conditions that shape the direction and dynamics of population movements are highlighted. The main problems of economic development and regional labour markets of the territories of the North Caucasus are outlined. In particular, the impact of migration on the regional labour market and changes in the demand structure of regional employment are assessed. It is concluded that the level of economic development, underdevelopment of social infrastructure and a high level of labour surplus creates conditions for the outflow and aspirations of young people to more economically developed territories of Russia.
\end{abstract}

Keywords: Migration, Labour market, North Caucasus.

\section{INTRODUCTION}

From the point of view of their impact on the labour market, the study of population migrations has been most actively engaged since the end of the 19th century, when there were global changes in the directions of migration flows.

In his work "The Laws of Migration" E.G. Ravenstein, [1] challenging the concept of chaotic development of migration processes that existed at that time, expresses the opinion that there are mainly economic patterns of the formation of population migrations. The "laws of migration" he described became the basis of the conceptual system of migrationology, which modern researchers then developed [2-4].

The impact that migrants have on the labour market and employment of the host territory, according to researchers, depends, among other things, on the territorial type of movement. It is believed that if we are talking about migration between different countries with different employment levels, then there will be no significant changes in the labour market in the whole country [5]. This is primarily due to the effect of replacing those areas of human activity that are least in demand on a country scale.

At the same time, it is necessary to consider that a large proportion of relatively young people are more often observed among migrant workers [6]. This affects both the nature of migration processes and the degree of impact of migration on the economy of receiving and giving regions, contributing to the transformation of the employment structure. Structural differences of migrants characterising their labour potential (level of education, professional competencies, age and gender) form qualitative characteristics of demand in the regional labour market and the degree of impact of migration processes on the socio-economic situation of receiving and giving regions.

\section{FEATURES OF THE FORMATION OF MIGRATION PROCESSES IN THE NORTH CAUCASUS}

Migration processes in the North Caucasus are represented by almost all types of interterritorial population movements. Historically, the region's population was characterised by withdrawal in search of 
earnings and due to the lack of the number of land resources necessary for agriculture in their native lands $[7,8]$.

In the 90s of the last century and the beginning of the "zero", the region faced a flow of forced migrants from armed conflict zones. In search of safe conditions, refugees mass-migrated to neighbouring safer regions [9].

Currently, labour migration in search of temporary or permanent earnings has become the most frequent type of displacement. This includes seasonal and pendulum migration, the exact scale of which is difficult to determine. Over the past decades, the gradual urbanisation of the region has played an essential role in forming migration trends. The resettlement of rural populations to urban areas is the most stable vector of population movement in the region over a long period.

At the same time, it should be noted that the increase in migration flows outside the region is characteristic, first of all, for the national republics of the North Caucasus. In this regard, the ethnic composition of the population is one of the structural features that shape migration processes in the region [10]. This may include the demographic structure of the population. On the other hand, the direction and dynamics of population movements are, to a certain extent, determined by the main socio-economic conditions, which will be discussed in the main part of the paper.

\subsection{Analysis of labour migration processes in the regions of the North Caucasus Federal District}

Migration processes in the North Caucasus, at present, are primarily due to factors that have economic reasons and are directly related to the situation in the regional labour market. Due to unemployment and general social instability, which has persisted for several decades, the outflow of residents of the republics of the North Caucasus continues to be quite significant [11]. A high level of labour surplus has been formed in the region, which, in turn, contributes to strengthening the population's departure from the region. The North Caucasus, in these processes, is, for the most part, a donor in internal Russian migration. The main objects of the

Table 1. Interregional labour migration of the employed population aged 15 years and older by the subjects of the Russian Federation in 2019 (according to a sample survey of the labour force)

\begin{tabular}{|c|c|c|c|c|}
\hline & \multicolumn{2}{|c|}{$\begin{array}{l}\text { The number of the employed } \\
\text { population, thousand people: }\end{array}$} & \multicolumn{2}{|c|}{$\begin{array}{l}\text { As a percentage of the } \\
\text { employed population of the } \\
\text { corresponding region }\end{array}$} \\
\hline & $\begin{array}{l}\text { entering to } \\
\text { work in the } \\
\text { subject }\end{array}$ & $\begin{array}{l}\text { travelling to } \\
\text { work in other } \\
\text { subjects }\end{array}$ & $\begin{array}{l}\text { entering to } \\
\text { work in the } \\
\text { subject }\end{array}$ & $\begin{array}{l}\text { travelling to } \\
\text { work in other } \\
\text { subjects }\end{array}$ \\
\hline Russian Federation & $2,928.0$ & $2,928.0$ & 4.1 & 4.1 \\
\hline Central Federal District & $1,800.7$ & $1,380.7$ & 8.7 & 6.7 \\
\hline North-Western Federal District & 298.0 & 233.2 & 4.1 & 3.2 \\
\hline Southern Federal District & 107.4 & 191.7 & 1.4 & 2.5 \\
\hline North Caucasus Federal District & 25.2 & 121.1 & 0.6 & 2.9 \\
\hline The Republic of Dagestan & 1.2 & 53.3 & 0.1 & 4.4 \\
\hline The Republic of Ingushetia & 3.8 & 0.3 & 2.0 & 0.2 \\
\hline The Kabardino-Balkarian Republic & 1.0 & 26.2 & 0.2 & 6.6 \\
\hline The Karachay-Cherkess Republic & 0.2 & 4.9 & 0.1 & 2.7 \\
\hline The Republic of North Ossetia-Alania & 1.0 & 8.0 & 0.4 & 2.9 \\
\hline The Chechen Republic & 7.1 & 2.6 & 1.3 & 0.5 \\
\hline The Stavropol Territory & 10.9 & 25.8 & 0.8 & 2.0 \\
\hline Volga Federal District & 106.4 & 662.7 & 0.8 & 4.7 \\
\hline Ural Federal District & 393.6 & 101.8 & 6.5 & 1.7 \\
\hline Siberian Federal District & 86.3 & 183.3 & 1.1 & 2.3 \\
\hline Far Eastern Federal District & 110.4 & 53.4 & 2.8 & 1.3 \\
\hline
\end{tabular}


departure and migration are still territories with the titular Russian population: Stavropol and Krasnodar Territories, Astrakhan, Volgograd and Rostov regions, and Moscow, Moscow region and St. Petersburg.

Table 1 presents statistical data on the results of interregional labour migration of the employed population of working age.

In almost all federal districts of Russia, the number of people who come to work on the territory of these districts usually exceeds the number of people leaving them, or their ratio is equal. The Volga and North Caucasus federal districts are strikingly different from other federal districts. They have approximately the same ratio of the incoming and outgoing population, and the number of people leaving for work in them is 5-6 times higher than incoming migrants. At the same time, residents of the North Caucasus Federal District travelling to work make up about $3 \%$ of the total number of working citizens.

Thus, in the more economically developed, among the North Caucasus Federal District territories, the Stavropol Territory, the number of residents leaving the region in search of earnings exceeds the number of those entering by 2.5 times.

The most significant number of people leaving for work is observed in the Republic of Dagestan and the Kabardino-Balkarian Republic (50 and 20 times compared to those entering). In the share of the employed population, their number is approximately $7 \%$ in Kabardino-Balkaria and 4\% in the Republic of Dagestan. Active outbound labour migration is often characteristic of the population of rural areas. The most significant number of rural citizens leave for work in construction, repair and agriculture. At one time, large-scale monitoring of labour migration in the Republic of Dagestan showed that the flows of labour migrants, intensity, volume and territorial orientation vary significantly by specific areas, natural and economic zones. The preferences of various ethnocultural, territorial and professional groups of the population also vary significantly when choosing directions and types of activities during labour migration [8].

The Chechen Republic and Ingushetia stand out positively against this background. In these regions, the excess in favour of the incoming population is 3-4 times, and in the share of the employed population, they are no more than $2 \%$. The explanation of the migration situation in the Republic of Ingushetia, which differs significantly from other territories of the North Caucasus with a high level of migration growth for several years, according to residents with whom the author of the study managed to communicate, is the active migration policy for the reception of refugees and compatriots, which the government of the region has carried out in recent years [12]. However, the scale recorded by Rosstat in this region cannot be explained only for this reason and is still not fully understood by experts [13] because the republic does not participate directly, for example, in the federal program for the return of compatriots from foreign countries.

If we return to the all-Russian situation, then the share of the able-bodied population participating in migration is slightly more than $4 \%$ in the whole country. The highest share of the employed is in the Central and Ural Federal Districts. In the Siberian and Southern Federal Districts, the number of employed migrants is the smallest.

\subsection{Economic prerequisites for interregional migration}

The high level of regional differentiation of socioeconomic development of the subjects of the Russian Federation has a significant impact on population migration.

According to most indicators of socio-economic development, the North Caucasus Federal District and, directly, the territories that make up it are in the lowest positions in the overall rank of federal districts of the Russian Federation.

The worst level of development, judging by the place occupied among other subjects of Russia, is occupied by the Republic of Ingushetia and the Kabardino-Balkarian Republic. The weighted average rank of these regions is 77th and 72nd place, respectively. The average rank occupied by the Republic of Dagestan is 62 .

In the national republics of the district, the rank value for the unemployment rate varies from 78 to 85 places, depending on the territory. The only exceptions are two indicators by which the region can be considered a leader among other subjects of the country - the share of paved roads in the total length of public roads and the volume of agricultural production.

The low level of economic development, the underdevelopment of social infrastructure and the high level of labour surplus creates conditions for the outflow and aspirations of young people to the more economically developed territories of Russia $[14,15]$.

In these conditions, when it becomes more and more challenging to ensure an acceptable standard and quality of life, part of the population is forced to change their usual places of residence. The flows of labour migrants from the subjects of the North Caucasus are increasing every year, and more and more citizens of working age consider leaving their home region as one of the alternatives when looking for a job.

At the same time, the direction of migration flows forms both an interregional and an intraregional vector of population movements. Especially in the North 
Caucasus, where, on the one hand, the level of urbanisation is relatively low and, on the other hand, the quality of life in rural areas, as well as throughout Russia, is significantly inferior to living conditions in the city.

\section{PROBLEMS OF ECONOMIC DEVELOPMENT OF THE NORTH CAUCASUS FEDERAL DISTRICT}

Almost $90 \%$ of the indicators of socio-economic development of the territories of the NCFD are at the lowest value in the overall rank among the rest of the federal districts of the Russian Federation. The only exceptions are two indicators - "The share of paved roads in the total length of public roads" and "The volume of agricultural production".

The worst level of development, judging by the place occupied among other subjects of Russia, is occupied by the Republic of Ingushetia and the Kabardino-Balkarian Republic. The weighted average rank of these regions is 76.9 and 71.9 , respectively. It is difficult to single out a certain indicator that the region is most lagging. We will highlight only such indicators as "GRP per capita" and "Receipt of taxes, fees and other mandatory payments to the budget system of the Russian Federation per capita". According to these data, the regions are at the very end of the list of subjects of the Russian Federation. Relatively high positions were noted here regarding the level of commissioning of residential buildings per 10,000 people of the population. The Republic of Ingushetia ranks 28th in terms of this indicator, and the Kabardino-Balkarian Republic ranks 30th.

\subsection{Features of the situation in the field of employment and the labour market in the $N C F D$}

In general, the employment sector in the region is underdeveloped; there is a relatively high unemployment rate in combination with a large number of the population at a young and working age. A high level of labour surplus has been formed in the region for decades.

In the regions of the North Caucasus Federal District in 2020, against the background of the spread of coronavirus infection, employment problems have only intensified, the number of jobs is decreasing, and the number of unemployed is growing [16]. Also, among the regions with the most challenging employment situation, the Republic of Ingushetia and the Chechen Republic have an unemployment rate of $30.7 \%$ and $21.7 \%$, respectively. In the Republic of North Ossetia-Alania and Dagestan, $16 \%$ are unemployed, slightly less $-15.4 \%$ in Kabardino-Balkaria [17].

Among the North Caucasus Federal District regions, almost 1.4 million workforce people are in the Republic of Dagestan and the Stavropol Territory. The number of employed is also the largest in the Stavropol Territory and the Republic of Dagestan - 1.2 and 1.1 million people, respectively. In the rest of the subjects of the Federal District, the total workforce is 1.8 million people.

The average rank occupied by the Republic of Dagestan is 61.7. The republic has one of the lowest levels of average monthly nominal wages, while, according to the level of per capita income, the region is in the middle of the ranking list of subjects of the Russian Federation. I.e., the official salary in the region is not the dominant component in the total amount of income received by citizens of the republic. In addition, this is a sign of a high share of officially unregulated incomes in the small and medium-sized business sector, and in general, the development of the shadow economy and shadow employment, in particular.

\section{CONCLUSION}

In conclusion, we will highlight the main directions of migration flows in the North Caucasus:

1. The stable for decades outflow of population, observed in all the territory of the Federal District, directed mainly to the more developed neighbouring Southern Federal District and the country's central regions.

2. The mass departure of young people is due to a shortage of jobs and a lack of opportunities for professional self-realisation.

3. The outflow of highly qualified and Russianspeaking population since the end of the last century.

4. Increased inbound labour migration from neighbouring countries and neighbouring regions.

5. Active migrations along the city-village line. In 2018, 103,417 people participated in intraregional migrations.

In the North Caucasus, the difficult situation with providing the younger generation with effective employment, the migration of the mountain population to the plains has been going on for several decades is getting worse.

The high unemployment rate characteristic of the North Caucasus Federal District territories, combined with the chaotic outflow of the population, becomes a factor constraining the region's economic development; there is a "washout" of the labour potential of the population during irrevocable departures.

Migration processes are becoming more active under the quantitative pressure of the population (the region is one of the most numerous in Russia) in the conditions of the economic backwardness of the North Caucasus Federal District subjects. Due to unemployment and general social instability, the migration outflow of the 
population outside their native republics continues to be significant. The main areas of relocation are still the regions of the Central Federal District and the most developed regions of the South of Russia: Stavropol and Krasnodar territories, Astrakhan, Volgograd and Rostov oblasts. Against the background of the fact that the region is relatively stable in demographic development (there are still high birth rates for many years), a high level of labour surplus in the region has formed in the region, which in turn contributes to an increased outflow of the population outside the region.

That is why it is vital to form an effective migration management strategy that considers this complex social process's structural and qualitative features. It is an effective tool for regulating and mitigating the imbalance and tension in the regional labour markets as receiving and giving regions.

\section{REFERENCES}

[1] E.G. Ravenstein, The Laws of Migration // Journal of the Statistical Society of London 48(2) (1885) 167-235.

[2] S.L. Everett, A Theory of Migration // Demography 3(1) (1966) 47-57.

[3] M.J. Piore, Birds of Passage: Migrant Labour and Industrial Societies, Cambridge: Cambridge University Press, 1979.

[4] I. Wallerstein, The Modern World-System, San Diego: Academic Press, Vol. III, 1989.

[5] V.Yu. Babyshev, The impact of labour immigration on the labour market [Vliyanie trudovoj immigracii na rynok truda] // Bulletin of Eurasian Science [Vestnik Evrazijskoj nauki] 1 (2020) 1-10.

[6] G.H.M. Evers, C.P.A. Bartels, Policy-Relevant Characteristics of Spatial Labour Mobility in The Netherlands: Monograph, IIASA, Laxenburg, Austria, 1981, p. 58.

[7] Sh.S. Muduev et al., Migration processes in Dagestan, Makhachkala: Ministry of Labour and Social Development of the Republic of Dagestan [Migracionnye processy v Dagestane. Mahachkala: Ministerstvo truda i social'nogo razvitiya Respubliki Dagestan], 2005, 122 p.

[8] E.M. Eldarov, et al. Employment and departure of the rural population of Dagestan [Zanyatost' i othodnichestvo sel'skogo naseleniya Dagestana] [Eldarov E.M., Efendiev I.I., Aliyev Sh.M., Gimbatov Sh.M.], Makhachkala: Nauka Plus, 2008, $200 \mathrm{p}$.

[9] S.V. Ryazantsev, Migration situation and migration policy in the North Caucasus [Migracionnaya situaciya i migracionnaya politika na Severnom Kavkaze] // Journal of Social Policy Research [Zhurnal Issledovanij Social'noj Politiki] 1(2) (2003) 153-168.

[10] Leonid Rybakovsky, Factors and causes of population migration, the mechanism of their interrelation [Faktory i prichiny migracii naseleniya, mekhanizm ih vzaimosvyazi] // Population [Narodonaselenie] 2(76) (2017) 51-61.

[11] M.M. Magomaev, E.M. Eldarov, Territorial differentiation of the living standard of the population of the South of Russia [Territorial'naya differenciaciya urovnya zhizni naseleniya yuga Rossii] // Proceedings of the Geographical Society of Dagestan [Trudy Geograficheskogo obshchestva Dagestana] XXXIII (2005) 49-53.

[12] A.K. Chapanov, Features of migration processes in modern Ingushetia [Osobennosti migracionnyh processov v sovremennoj Ingushetii] // Caspian Region: Politics, Economy, Culture [Kaspijskij Region: Politika, Ekonomika, Kul'tura] 1(46) (2016) 92-98.

[13] N.V. Mkrtachyan, Migration in the North Caucasus through the prism of imperfect statistics [Migraciya na Severnom Kavkaze skvoz' prizmu nesovershennoj statistiki] // Journal of Social Policy Research [Zhurnal issledovanij social'noj politiki] 17(1) (2019) 7-22.

[14] I.A. Soloviev, Regional features of migration processes in the North Caucasus [Regional'nye osobennosti migracionnyh processov na Severnom Kavkaze]: 1(44) // Geographical Bulletin. Russia, Perm: Federal State Budgetary Educational Institution of Higher Professional Education "Perm State National Research University" [Geograficheskij vestnik. Rossiya, Perm': Federal'noe gosudarstvennoe byudzhetnoe obrazovatel'noe uchrezhdenie vysshego professional'nogo obrazovaniya «Permskij gosudarstvennyj nacional'nyj issledovatel'skij universitet»] 1(44) (2018) 49-55.

[15] V.N. Schensnovich, Migration processes in the North Caucasus (analytical review) [Migracionnye processy na Severnom Kavkaze (analiticheskij obzor)]: 4(314) // Russia and the Muslim world. Russia, Moscow: Federal State Budgetary Institution of Science "Institute of Scientific Information on Social Sciences of the Russian Academy of Sciences" [Rossiya i musul'manskij mir. Rossiya, Moskva: Federal'noe gosudarstvennoe byudzhetnoe uchrezhdenie nauki «Institut nauchnoj informacii po obshchestvennym 
naukam Rossijskoj akademii nauk»] 4(314) (2019) 23-38.

[16] Sh.M. Gimbatov, The Impact of Changes in SocioDemographic Characteristics on the Reproduction of Labour Resources in the Regions of the North Caucasus [Vozdejstvie Izmenenij Social'noDemograficheskih Harakteristik Na Vosproizvodstvo Trudovyh Resursov V Regionah Severnogo Kavkaza]. Donetsk National Technical University [Doneckij nacional'nyj tekhnicheskij universitet], 2021, pp. 369-373.

[17] BoE - Russian Statistical Yearbook 2019 [BGD Rossijskij statisticheskij ezhegodnik 2019] [Electronic resource]. URL: https://www.gks.ru/bgd/regl/b19_13/Main.htm (accessed: 01.12.2021). 